\title{
Phacoemulsification in hard cataracts: The "chop, trip and free" technique
}

\author{
Facoemulsificaçãoem cataratasduras: "Facorasteira"
}

José Marcos S. Gonçalves

Trabalho realizado no Hospital de Clinica e Cirurgia Ocular (HCO).

Médico Oftalmologista do Hospital de Clínica e Cirurgia Ocular (HCO) Uberlândia.

Address to correspondence: José Marcos Santos Gonçalves - Hospital de Clínica e Cirugia Ocular. Av. Getúlio Vargas, 1666 - Uberlândia (MG) CEP 38412-066 E-mail:jmarcos@nanet.com.br

Recebido para publicação em 27.11.2003

Versão revisada recebida em 19.04.2004

Aprovação em 30.04.2004

\begin{tabular}{|l|}
\hline ABSTRACT \\
\hline Very hard cataracts continue to be a challenge to phacoemulsification due \\
to the difficulty in breaking the nucleus and also in separating the broken \\
nucleus from the adjacent epinucleus. The present technique is the pre- \\
sentation of a surgical maneuver which uses the Nagahara chopper and the \\
phaco tip to divide the nucleus (including the epinucleus) as a whole and \\
then emulsify it using little time and not very much phaco power. \\
\hline
\end{tabular}

Keywords: Phacoemulsification/methos; Cataract; Lens nucleus, Crystalline/surgery; Capsulorhexis/methods

\section{INTRODUCTION}

As the lens ages, it increases in weight and thickness. As new layers of cortical fibers are formed concentrically, the lens nucleus undergoes compression and hardening (nuclear sclerosis). Crystallins (lens proteins) are changed by chemical modification and aggregation into high-molecularweight proteins ${ }^{(1)}$.

In the hard and even in the very hard ${ }^{1}$ nuclei (or the rock-hard lens that is composed of almost all densely compacted, sclerotic endonucleus with very little surrounding epinucleus ${ }^{(2)}$ ) phacoemulsification requires a technique that allows this crystalline to be broken in order to be emulsified. There are several techniques used for this purpose however, high intensity of phaco power and much time is needed to achieve the emulsification of the hard nuclei. Since high phaco power is necessary, this poses risks to the cornea and all anterior chamber tissues causing severe inflammation and loss of endothelial cells. The greatest challenge in phacoemulsifying these nuclei is breaking them down because it is difficult to separate the hardened and compressed cortical fiber layers.

The present study is the description of a technique in which the cataract is emulsified without the need of using a great amount of phaco power for an extended amount of time.

\section{SURGICAL TECHNIQUE}

Preoperatively, $1 \%$ tropicamide and $10 \%$ phenylephrine eye drops are administered every 10 to 20 minutes until a good mydriasis is obtained.

In the cases of very hard cataracts, a peribulbar injection of $2 \%$ lidocaine without adrenaline is given with a 25/7-gauge needle. In hard cataracts, topical anesthesia with $0.5 \%$ bupivacaine chlorhydrate is given 4 times at an interval of 10 minutes before beginning of surgery.

Clear cornea temporal incision is performed with a $2.8 \mathrm{~mm}$ diamond blade and a $1 \mathrm{~mm}$ paracentesis is performed, clockwise $30^{\circ}$ from the main incision, to 
introduce the hook. In most surgeries, $0.1 \%$ tripan blue is used to make it easier to visualize the curvilinear capsulorrhexis. The diameter varies from 5 to $5.5 \mathrm{~mm}$. Dispersive viscoelastic is applied in all cases. The hydrodissection is confirmed by rotating the nucleus to certify that it is totally free inside the capsular bag.

The Legacy of Alcon equipment with flared ABS tips in phacoemulsification is used according to the following characteristics: ranging from $40 \%$ to $50 \%$ maximum power with 3 pulses, $500 \mathrm{mmHg}$ maximum vacuum, $50 \mathrm{ml} / \mathrm{min}$ aspiration flow rate.

Phacoemulsification begins with the phaco tip positioned with the bevel downward in the central area of the lens, so that it penetrates $2 / 3$ inside when the breaking maneuver is being performed.The Nagahara hook is inserted into the bag opposite to the phaco tip. Due to the hardness of the nucleus, in many cases it is not possible to totally break down the nucleus, because the posterior crystalline lens fibers or hard epinucleus (the latter is a clinical term used to describe the outermost part of the nucleus or the innermost part of the cortex $^{(1)}$ are intertwined (Figure 1A). By rotating the lens, several pieces of nucleus are broken ("chopped") in the whole circumference (Figure 2A). At the end, the epinucleus area is not totally divided. In this situation, phacoemulsification and aspiration are very difficult to be performed.
At this time the "chop, trip and free" technique begins. It consists of holding together each piece of fragmented nucleus with the vacuum of the phaco tip, pushing it slightly through and pulling it back in the plan of the iris. Simultaneously, the Nagahara hook with its tip in the horizontal position and parallel to the posterior capsule is introduced below the piece of nucleus and epinucleus in the periphery (Figures 1B, 1C, 2B). Moving the hook in a "tripping" motion, opposite (centripetal) to the movement of the phaco tip, the part of the epinucleus which is adhered to the central portion is liberated ("freed") by the hook (Figures 1D, 2C). Once free, this piece is emulsified and aspirated, using high vacuous with little phaco power, following the previously described parameters. All other pieces which are adhered follow the same sequence.

When the whole phacoemulsification is done, the surgery has been performed with high vacuum, but with very little phaco power.

\section{DISCUSSION}

The posterior chamber is now considered the preferred location for hard nucleus phacoemulsification. ${ }^{1}$ In cases of hard nuclei that are emulsified as a whole in the anterior
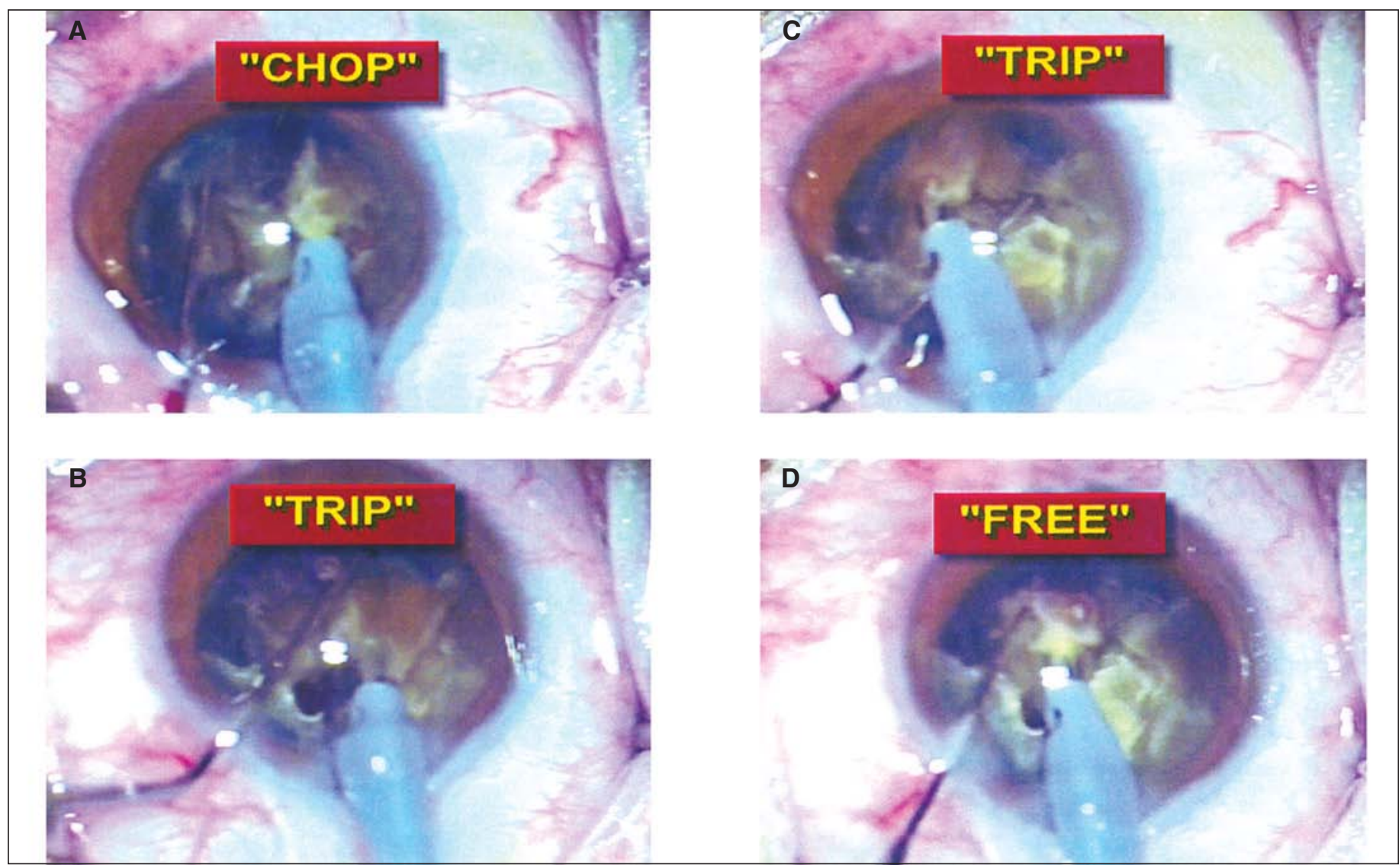

Figura 1 - A:Breaking the endonucleus; B:Nagahara hook below the piece of nucleus and epinucleus in the periphery; C:Tripping motion; D:Each piece of nucleus and epinucleus is free (liberated) to be emulsified 

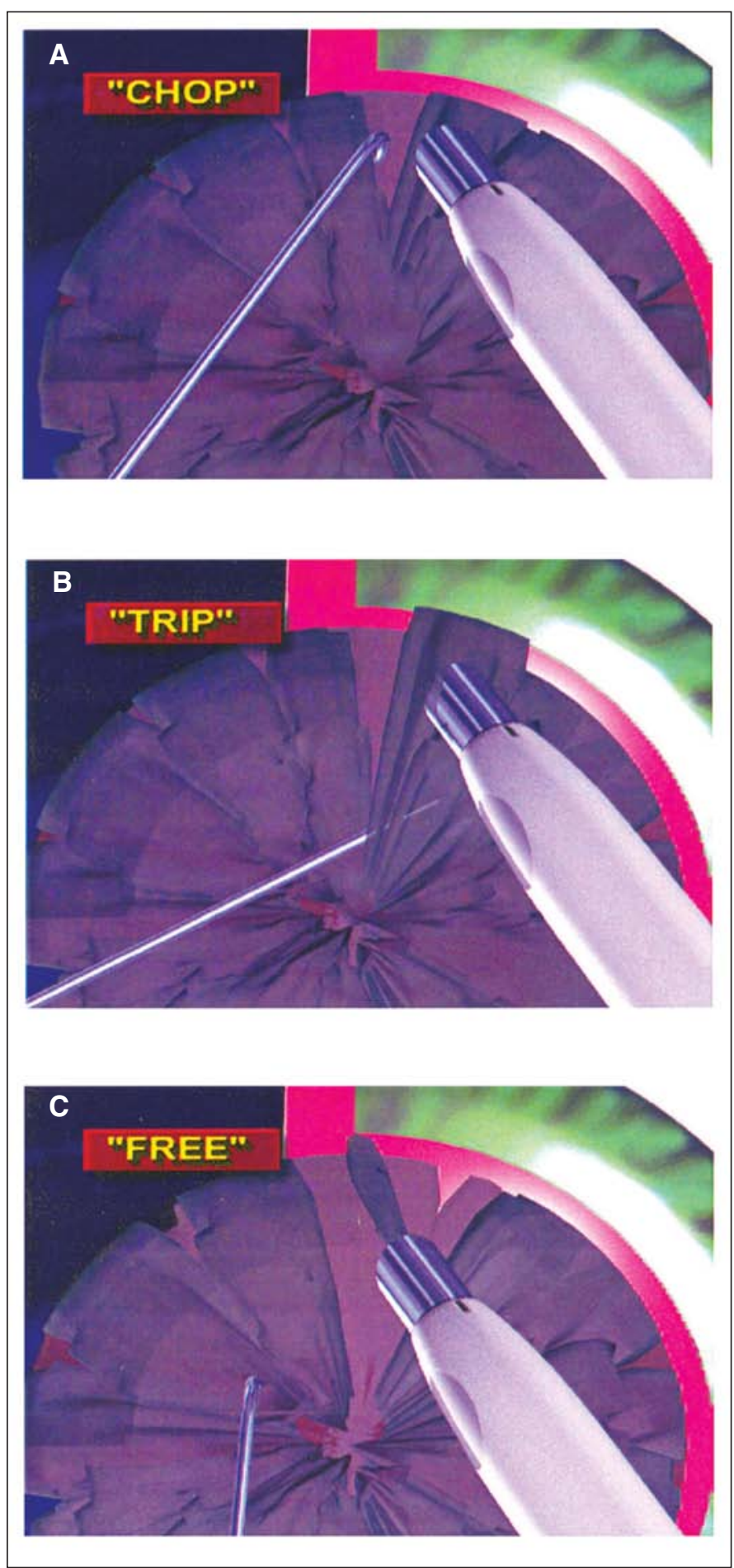

Figura 2 - A:Several pieces of nucleus chopped; B:Nagahara hook below the piece of nucleus and epinucleus in the periphery; C: Each piece of nucleus and epinucleus is free (liberated) to be emulsified

chamber, in the plane of the iris, or in the posterior chamber, much of ultrasound is necessary and consequently significant endothelial trauma occurs.

Other techniques which are used currently, such as divide and conquer described by Gimbel ${ }^{(3)}$, phaco chop made popular by $\mathrm{Koch}^{(4)}$, and others ${ }^{(5)}$, need a longer time of phaco power to sculpt the nuclei and to obtain pieces. In the chop technique, described by Nagahara ${ }^{(6)}$ and others ${ }^{(5)}$, total breakdown of the nucleus and epinucleus is often not achieved in some hard and very hard cataracts.

It was by facing difficulties in the phacoemulsifications of these cataracts found in Brazil, a developing country, that this technique was proposed: chopping the nucleus using the Nagahara chopper to "trip" and free the epinuclear pieces, which were not totally divided and separated, using high vacuum and very little phaco power were the main features of this technique. In this procedure, risk to the cornea was avoided.

Other advantages of this technique include reduced stress on the capsular bag and zonular fibers.

In conclusion, the "chop, trip and free" technique is a safe and reproducible procedure which facilitates the surgical correction of the hard and very hard cataracts for an experienced surgeon.

\section{ACKNOWLEDGEMENT}

Most respectfully I have a great debt of gratitude to João Brasil Vita MD, from the Universidade Federal de São Paulo, who wisely gave me the incentive to write this article and guided me in the right direction. I want to offer him my humble tribute and many thanks for his support.

\section{RESUMO}

Cataratas muito duras continuam sendo um desafio para a facoemulsificação devido à dificuldade em quebrar o núcleo e também em separar este pedaço quebrado do epinúcleo adjacente. Esta técnica é a apresentação de uma manobra cirúrgica ("Faco rasteira”), em que se utiliza o Nagahara "chopper" e a caneta de faco para dividir o núcleo (incluindo o epinúcleo) em sua totalidade e assim emulsificá-lo, utilizando tempo e poder de ultra-som baixo.

Descritores: Facoemulsificação/métodos; Catarata; Núcleo do cristalino/cirurgia; Capsulorrexe/cirurgia

\section{REFERENCES}

1. American Academy of Ophthalmology. Lens and cataract. San Fransisco, CA, American Academy of Ophthalmology,1998. [ Basic and Clinical Science Course, Section 11].

2. Dillman DM. Endolenticular phacoemulsification. Int Ophthalmol Clin. 1994;34(2):91-101.

3. Gimbel HV. Divide and conquer nucleofractis phacoemulsification: development and variations.. J Cataract Refract Surg. 1991;17(3):281-91.

4. Koch PS. Mastering phacoemulsification: A simplified manual of strategies for the spring. crack, and sop and chop technique. Thorofar, NJ: Slack, 1994.

5. Arshinoff SA. Phaco slice and separate. J Cataract Refract Surg. 1999;25(4):474-8.

6. Nagahara K. Phaco chop [videotape]. Presented at the American Society of Cataract and Refractive Surgery fim festival, Seattle, 9-12 May 1993. 